\title{
The market trend analysis and prospects of scaffolds for stem cells
}

Seou Lee ${ }^{1 \dagger}$, Taehoon Kwon ${ }^{2 \dagger}$, Eun Kyung Chung ${ }^{2}$ and Joon Woo Lee ${ }^{2 *}$

\begin{abstract}
Background: Scaffolds are one of the three most important elements constituting the basic concept of regenerative medicine, and are included in the core technology of regenerative medicine along with stem cells and tissue engineering. Stem cells are very important technology because they are directly responsible for the regenerative treatment of the disease and the damaged tissue, but with regards to the technology and the products that use stem cells exclusively, there is a technical limitation of limited survival rate and the engraftment rate of the transplanted cell, and rather than recovering the damaged tissue fundamentally, there is a limit that the concept is more of just another medicine treatment using cells.

A scaffold is a natural or synthetic biocompatible material transplanted into a human body to be used as the exclusive treatment or as an assisted method of another treatment of a disease and for the recovery of damaged tissue. Therefore, according to the characteristics of the tissue to be applied, scaffolds must have the characteristics such as the excellent biocompatibility, biodegradability, minimum immunity and inflammation, proper mechanical strength and interaction between the material and the cells.

Results: The world stem cell market was approximately 2.715 billion dollars in 2010, and with a growth rate of $16.8 \%$ annually, a market of 6.877 billion dollars will be formed in 2016. From 2017, the expected annual growth rate is $10.6 \%$, which would expand the market to 11.38 billion dollars by 2021 . Meanwhile, the world scaffold element technology market was approximately 4.57 million dollars in 2013, and by increasing $13.4 \%$ annually, it is estimated to expand to 10.63 million dollars by 2020. The Korean scaffold element technology market was about 22 million dollars in 2013 , and with a steady growth of approximately $13.4 \%$ every year, it is prospected to be about 52 million dollars by 2020.
\end{abstract}

Conclusions: In comparison to the medical material and medicine sales growth rate, the future scaffold element technology market is judged to be higher in growth possibility.

Keywords: Regenerative medicine, Stem cell, Tissue engineering, Scaffold, Market analysis

\section{Background}

In the modern society, due to developments in technology and industry, there are increasing cases of defunctionalization or damage to tissues or organs from various accidents, diseases, and aging, and as the human body reaches its limits in self-regeneration ability, the need for proper and effective treatment methods is increasing rapidly [1-3].

For the treatment of damaged tissue or organs, organ transplantation from donors or animals is often attempted,

\footnotetext{
* Correspondence: jwlee@kisti.re.kr

${ }^{\dagger}$ Equal contributors

${ }^{2}$ KISTI, 66 Heogi-ro, Dongdeamoon-gu, Seoul 130-741, Korea

Full list of author information is available at the end of the article
}

but there are many problems such as a lack of organ donors, immune rejection response, and animal-derived viruses [4-8]. Therefore, the tissue engineering approach of using biomaterials to effectively substitute for or transplant a replacement of damaged biological tissues or organs while avoiding these problems is coming to the fore, and thus there is a need for various studies on these research topics [8-12].

Accordingly, studies on biomaterials useful in tissue regeneration are actively being conducted to design materials that can induce the regeneration of the damaged tissue or organ. Research is also currently being done on stem cell differentiation within scaffolds and mechanisms of the tissue regeneration on transplant to the 
human body and efforts on the development and application of its therapeutic method [13]. However, it is very difficult to form three-dimensional artificial organ similar to the structurally complex tissue within the human body due to the technical limits in the biomaterial development.

\section{Methods}

Data for this research were gathered from primary and secondary sources as well as the databases of the Korea Institute of Science Technology Information. The key areas of the research process are described below.

\section{Primary research}

Primary research sources relied for the databases of Korea Institute of Science Technology Information, past industry research service/study, economic and demographic data, and trade and industry journals. This research was conducted to map and analyze market and technology trends.

\section{Secondary research}

Secondary research was used to supplement and complement the primary research. Interviews were conducted with physicians and surgeons from the key hospitals and senior sale/marketing managers from cell therapy product suppliers in South Korea.

\section{Results and discussion}

\section{Concept and characteristics of scaffolds}

Scaffolds are one of the three most important elements constituting the basic concept of regenerative medicine, and their role is adhesion and differentiation of the cells disseminated inside and outside of their structure, and the basis for providing the proper environment for cell proliferation and differentiation moving from the surroundings of the tissue and for providing the tissue form required [14]. Also, scaffold technology is included in the core technology of regenerative medicine along with stem cells and tissue engineering.

Stem cells are the most important technology because they directly take charge of regenerative therapy on the disease and the damaged tissue [15], but it is not easy to realize regenerative medicine's goal of "fundamental recovery of the damaged tissue and organ" with stem cells alone [16]. Currently, various types of stem cells such as autologous and allogeneic adult stem cells, embryonic stem cells (ESCs), and induced pluripotent stem cells are being used in many attempts to cure disease, and for the adult stem cells, some products have already been developed for commercialization. However, technology and products using stem cells exclusively have technical limitations due to the limited survival rate and engraftment rate of the transplant cell, and with these limits, stem cell treatment become more of a concept of another medicine treatment using cells rather than a way to recover the damaged tissue fundamentally. In an attempt to overcome this technical limit, biomaterial technology for the transplant and delivery of stem cells and tissue engineering technology for engrafting biomaterials are being actively studied.

The scaffold is a natural or synthetic biocompatible material transplanted into the human body for the treatment of the disease and recovery of the damaged tissue, used exclusively or as a means of assistance to another treatment $[14,17]$. Therefore, according to the excellent biocompatibility, biodegradability, minimum immunity and inflammation, proper mechanical strength, interaction between the material and the cell, interconnected porosity structure, and the characteristics of the tissue to be applied, characteristics such as the proper mechanical strength are required [18].

Currently, the biomaterials used clinically for the transplant of stem cells are natural biomaterials such as collagen, fibrin, chitosan, keratin, peptide, hyaluronate, hydrogel, silk protein, hydroxyl, and tri-calcium phosphate as well as approved medical macromolecules with biocompatibility with synthetic biomaterials such as PLA, PGA, PLGA, and PLC [18-22]. Natural biomaterials have excellent bio-functionality such as biocompatibility and biodegradability but have the disadvantages of limited mechanical and physical strength and low processability. On the other hand, synthetic biomaterials can be controlled the characteristics of their excellent mechanical property, flexible processability. Among the synthetic biomaterials, biodegradable biomaterials that self-degrade after inducing the regeneration and recovery of tissue in the human body are being studied greatly.

Researchers in tissue engineering technology have been mounting stem cells on biomaterials and cultivating them inside or outside the human body to produce artificial organs similar in structure and function to actual human tissues or organs.

Regarding current status of the biomaterial development technology in Korea, there are companies developing and producing single products such as badges. Most Korean biomaterial companies are focused on cell therapy products using cells rather than on producing primary cultured cells for studies or stem cells R\&D. However, in other parts of the world, many companies are developing and commercializing cells and cultured elements such as primary cultured cells for study, stem cells, culture mediums, and coatings.

\section{Characteristics of the stem cell technology industry}

Scaffold technology is applied as the element in the regenerative medicine field, relevant to the stem cell industry and also to the regenerative medicine industry by extension. Regenerative medicine is a high-tech convergence 
technology field of regenerating or substituting for a tissue and organ that is damaged or malfunctioning due to aging, disease, and an accident. Also, regenerative medicine is emerging as an alternative to treating intractable diseases such as dementia, diabetes, and spinal cord injury for which no proper therapy method currently exist, and it is being applied in various fields such as customized cell therapy products, biological tissues, and in bio-organ development. Regenerative medicine is receiving attention as a new growth engine to create enormous economic added value.

When we look at the main characteristics of the regenerative medicine technology and industry, it first becomes apparent that regenerative medicine technology mainly focuses on intractable and chronic diseases; therefore, there is a great demand for clinical treatment. Second, since unlike in the existing drug therapies, the subject is a living cell, there are technical and procedural difficulties in the process of approval. Third, because it is mostly transplanted through surgical processes, optimization and standardization of the clinical protocol and new medical technology and improvement in the health insurance system are required. Lastly, verification of clinical safety and effectiveness through long-term observation is very important.

The stem cell industry is a field which will likely develop in various areas such as cell therapy products, new drug developments, and bio-tissue engineering, which will be used widely in disease treatment. Since it is a new field that has not yet established its overall technology system, various types of research and development are being attempted for industrialization and performance creation. Due to the lack of R\&D manpower and low technology maturity in the stem cell industry, there are many technical difficulties to overcome before actual commercialization can occur, but depending on future $R \& D$ efforts, the growth potential is high, and the market entry barrier is relatively low, which means that it is a field with high development possibility. Also, it is a high value-added application field that is based on biotechnology and converged with high technology such as IT, NT, etc. The industry not only has added-value on the medicine itself based on regenerative effects, but it also has front and back linkage effects with the medical industry, and high quality employment can be created with the advanced country type knowledge-based technology. Due to the long development period and high risk in the industrialization process, it is also a field that is generalized by government-led R\&D support worldwide (Table 1).

\section{Korean and world scaffold market size and prospects}

Regarding the market for scaffolds, which are a biomaterial and one of the core element technologies in regenerative medicine, the scaffolds market data is very insufficient for clearly understanding and estimating its scope and size.

The element technology market for scaffolds has the characteristic of high relating effect with the front industry; therefore, the market trend, size, and prospects for scaffolds will be assumed to be similar to the trend of the front industry, the stem cell and regenerative medicine industry, and will be estimated using data from that industry.

Table 1 Technology field and contents related to stem cells [23]

\begin{tabular}{|c|c|}
\hline Technology field & Contents \\
\hline \multirow[t]{2}{*}{$\begin{array}{l}\text { Bio-tissue engineering and engineering of bio- } \\
\text { organs using stem cells }\end{array}$} & $\begin{array}{l}\text { - The regenerative ability of the stem cell is used to culture the stem cell and the supporting cells, } \\
\text { and the widely-differentiated tissue and organ regenerates the damaged tissue or organ to enable } \\
\text { the treatment of the disease. }\end{array}$ \\
\hline & $\begin{array}{l}\text { - The bio-tissue using stem cell is high in biocompatibility and low in immune-rejection, expected } \\
\text { to possess a big strength as the tissue engineering product. }\end{array}$ \\
\hline \multirow[t]{2}{*}{$\begin{array}{l}\text { Cell therapy product development using stem } \\
\text { cells }\end{array}$} & $\begin{array}{l}\text { - The stem cell extracted from the patient is differentiated/proliferated in a specific environment and } \\
\text { injected into the relevant patient to substitute for the function of the damaged cell and tissue }\end{array}$ \\
\hline & $\begin{array}{l}\text { - The universality of the stem cell is expected to innovate in all medical fields of the cardiovascular } \\
\text { system, the nervous system, the blood and immune system, the bone and cartilage system, and in } \\
\text { the skin. }\end{array}$ \\
\hline \multirow[t]{3}{*}{$\begin{array}{l}\text { Efficiency of new drug development using } \\
\text { stem cells }\end{array}$} & $\begin{array}{l}\text { - Stem cells are differentiated into specific disease cells to discover candidate materials for new } \\
\text { drugs, and the effectiveness verification is quickly performed in large quantities to improve the } \\
\text { efficiency of new drug development. }\end{array}$ \\
\hline & $\begin{array}{l}\text { - During the clinical test process in new drug development, stem cells are differentiated into various } \\
\text { cells and tissues, which are expected to verify the toxicity of the candidate material for the new } \\
\text { drug more easily and quickly. }\end{array}$ \\
\hline & $\begin{array}{l}\text { - The cancer stem cell is the original material for anticancer drug development and for initial } \\
\text { diagnostic technology development of cancer, prospected to be utilized in new anticancer drug } \\
\text { and diagnostic agent development. }\end{array}$ \\
\hline
\end{tabular}


Therefore, to estimate the Korean and world market size and prospects for scaffold element technology, the following data related to the stem cell market are considered.

First, total world market size, prospects, and growth rate of the stem cell field in which scaffolds are applied are identified. The world stem cell market was approximately 2.715 billion dollars in 2010 and with a $16.8 \%$ growth rate annually, the market will be 6.877 billion dollars in 2016 with an annual average growth of 10.6\% starting in 2017, the market is prospected to expand to 11.38 billion dollars by 2021 [1] (Table 2).

Second, in the stem cell market, the market size of which scaffold element technology is included is assumed. As we can see in Table 3, the element technology field, which is classified into cell lines, cell culture fluid, and cell carriers, occupies an average of about $10.15 \%$ (2010 2015) of the total technology market related to cell treatment, and from 2005 to 2015, an annual average growth rate of $17.2 \%$ is prospected [24].

Third, the world stem cell market is estimated to grow rapidly from 1.1 billion dollars in 2012 to 16 billion dollars by 2020 with an annual growth rate of $39.7 \%$. Within this, the world market size of the cell culture and consumables market, including the scaffold development technology market, was 320 million dollars in 2012 and is prospected to expand to 420 million dollars in 2015. Also, in 2011, the Korean sales related to stem cells make up a small-sized market of approximately 54 billion won, estimated to include 40 billion won in cord blood storage and 14 billion won in medicine, and the market of the consumables and instrument sector in which scaffold technology is included is reported as not being formed [25].
Through these results, we can estimate that the Korean stem cell market size is about $4.9 \%$ of the world market, and this percentage can also be applied to the scaffold element technology market (Figure 1).

If we use the data above to estimate the market size and prospects of the Korean and world scaffold element technology markets, the world scaffold element technology market was approximately 457 million dollars in 2013, and by growing $13.4 \%$ annually, the market will expand to 1.063 billion dollars in 2020. The Korean scaffold element technology market was 22 million dollars in 2013, and through a steady increase of $13.4 \%$ like the world annual average growth rate, it is prospected to be 52 million dollars in 2020. In the last three years, the sales growth rate of the same industry, medical materials and medicine was $6.3 \%$, which is $2.2 \%$ higher than the $4.1 \%$ of the last three years' average economic growth rate, and the average estimated sales growth rate for the next 5 years of the market in which the evaluation technology is included is $13.4 \%$. As it exceeds the recent average economic growth rate of $4.1 \%$, it is judged that the growth possibility of the scaffold element technology market is high (Table 4).

\section{Relevant industry trend}

Though approximately 500 companies are participating in the tissue engineering field worldwide, these companies are very difficult to identify precisely due to frequent change in company names, mergers, and acquisitions. Of the approximately 500 companies, about 303 of them are located in the US, the UK, Germany, Japan, or Sweden. About 230 companies are closely related to regenerative

Table 2 World market analysis and prospects of stem cells [1]

\begin{tabular}{|c|c|c|c|c|c|c|c|c|c|c|c|c|}
\hline & 2010 & 2011 & 2012 & 2013 & 2014 & 2015 & 2016 & 2017 & 2018 & 2019 & 2020 & 2021 \\
\hline Stem cells market $(\$ \mathrm{~m})$ & 2,715 & 3,238 & 3,819 & 4,500 & 5,208 & 6,006 & 6,877 & 7,747 & 8,658 & 9,551 & 10,471 & 11,380 \\
\hline Annual growth (\%) & & 19 & 18 & 18 & 16 & 15 & 14 & 13 & 12 & 10 & 10 & 9 \\
\hline CAGR (\%) & & & & & & & 16.8 & & & & & 10.6 \\
\hline Stem cells services (\$m) & 1,420 & 1,647 & 1,894 & 2,178 & 2,462 & 2,782 & 3,115 & 3,427 & 3,770 & 4,109 & 4,479 & 4,882 \\
\hline Annual growth (\%) & & 16 & 15 & 15 & 13 & 13 & 12 & 10 & 10 & 9 & 9 & 9 \\
\hline CAGR (\%) & & & & & & & 14.0 & & & & & 9.4 \\
\hline Cord blood banking ( $\$ \mathrm{~m})$ & 1,120 & 1,344 & 1,572 & 1,824 & 2,061 & 2,288 & 2,517 & 2,743 & 2,963 & 3,200 & 3,424 & 3,629 \\
\hline Annual growth (\%) & & 20 & 17 & 16 & 13 & 11 & 10 & 9 & 8 & 8 & 7 & 6 \\
\hline CAGR (\%) & & & & & & & 14.4 & & & & & 7.6 \\
\hline Stem cell therapies $(\$ m)$ & 125 & 194 & 296 & 439 & 623 & 872 & 1,177 & 1,507 & 1,854 & 2,169 & 2,494 & 2,794 \\
\hline Annual growth (\%) & & 55 & 53 & 48 & 42 & 40 & 35 & 28 & 23 & 17 & 15 & 12 \\
\hline CAGR (\%) & & & & & & & 45.3 & & & & & 18.9 \\
\hline Bone marrow transplants $(\$ \mathrm{~m})$ & 50 & 53 & 56 & 59 & 62 & 64 & 67 & 70 & 72 & 73 & 75 & 75 \\
\hline Annual growth (\%) & & 6 & 6 & 5 & 5 & 4 & 4 & 4 & 3 & 2 & 2 & 1 \\
\hline CAGR (\%) & & & & & & & 5.0 & & & & & 2.4 \\
\hline
\end{tabular}


Table 3 Cell treatment market size and prospects (unit: 100 million dollars) [24]

\begin{tabular}{|c|c|c|c|c|}
\hline Technology & 2005 & 2010 & 2015 & CAGR \\
\hline Stem cells & 20 & 52 & 109 & $18.5 \%$ \\
\hline Cord blood & 5 & 10 & 23 & $16.5 \%$ \\
\hline Tissue engineering & 69 & 135 & 232 & $12.9 \%$ \\
\hline Transfusion products & 128 & 224 & 350 & $10.6 \%$ \\
\hline Cell-based gene therapy & 15 & 30 & 59 & $14.7 \%$ \\
\hline Capsule cell treatment & 4 & 19 & 31 & $22.7 \%$ \\
\hline Cell-based cancer vaccines & 9 & 16 & 29 & $12.4 \%$ \\
\hline Heteroplastids & 6 & 19 & 32 & $18.2 \%$ \\
\hline Element technology(Cell lines, cell culture fluid, cell carriers) & 20 & 57 & 98 & $17.2 \%$ \\
\hline Total & 276 & 562 & 963 & $13.3 \%$ \\
\hline
\end{tabular}

medicine, and about 27 of these companies are focusing on the discovery and development of drugs using stem cells, while another 27 companies are focusing on application programs. Therefore, 148 companies are developing biomaterials such as scaffolds, showing that it is not a small number compared to the total number of tissue engineering companies.

Along with developing biomaterials, some companies are combining stem cells to develop tissue engineering products for each tissue. Seventy-three companies are investigating how to develop tissue engineering products. The areas of competitive activity are the US and the UK, and there is a severe variability between the companies in these areas. It is especially difficult to identify the relevant companies in the US due to changes in company names Generally, large public companies are participating in regenerative medicine, other companies are sufficiently performing the core activity, and some companies are devoting their efforts to developing target products in the new business field [18].

Companies and research institutes related to tissue engineering share more knowledge and information and promote industrial development when they concentrated nationally or geographically to form a strong cluster. When we look at the geographic distribution of tissue engineering firms and research institutes (Figure 2), the US is the highest with $52 \%$, followed by Germany (21\%), Japan (16\%), the UK (7\%), and Sweden (4\%) [18].

In Korea, there are no companies selling scaffold products, but there are $R \& D$ results. In 2012, The Korea University mechanical engineering department research team used micro-fluid technology to fix the extracellular matrix such as collagen to succeed in developing the technology of culturing various cells three-dimensionally.
Total 160

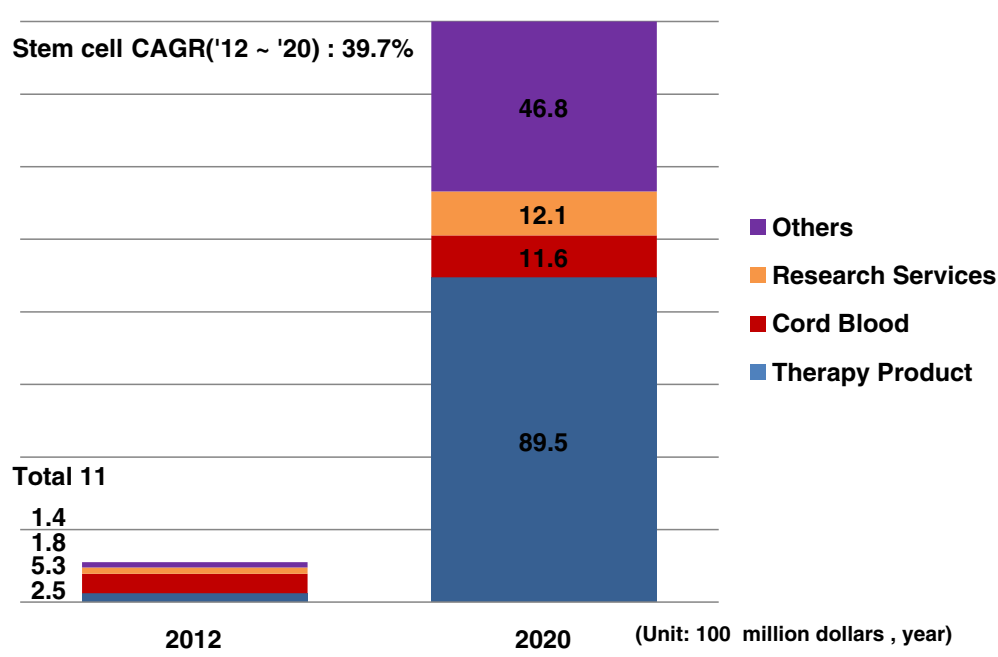

Figure 1 World market prospects of stem cells [25]. 
Table 4 Korean and world scaffold element technology market size and prospects (unit: million dollars)

\begin{tabular}{lllllllllll}
\hline Division & $\mathbf{2 0 1 2}$ & $\mathbf{2 0 1 3}$ & $\mathbf{2 0 1 4}$ & $\mathbf{2 0 1 5}$ & $\mathbf{2 0 1 6}$ & $\mathbf{2 0 1 7}$ & $\mathbf{2 0 1 8}$ & $\mathbf{2 0 1 9}$ & 2020 & CAGR ('12 '20) \\
\hline World stem cell market & 3,819 & 4,500 & 5,208 & 6,006 & 6,877 & 7,747 & 8,658 & 9,551 & 10,471 & $13.4 \%$ \\
World scaffold element technology market $(\times 10.15 \%)$ & 388 & 457 & 529 & 610 & 698 & 786 & 879 & 969 & 1,063 & \\
Korean scaffold element technology market $(\times 4.9 \%)$ & 19 & 22 & 26 & 30 & 34 & 39 & 43 & 48 & 52 & \\
\hline
\end{tabular}

In other parts of the world, there are many multinational companies related to three-dimensional cell culture, and among them, BD Biosciences has the highest awareness, followed by Life Technologies(Invitrogen), Corning, 3D Biotek, and Insphero.Also, among the companies related to three-dimensional cell culture consumables and instruments, BD Biosciences is the largest with a $27 \%$ market share, followed by Life Technologies(Invitrogen) (16\%), Corning (11\%), Sigma-Aldrich (8\%), Lonza(6\%), Insphero (4\%), 3D Biotek(4\%), and Global Cell Solutions (3\%), showing that there are many companies competing (Table 5 and Figure 3).

The following are world cell and tissue suppliers, represented by American Type Culture Collection(ATCC), Asterand plc, BioE, Life technologies, Cell Systems Biotechnologie Vertrieb GmbH, and Lonza Group Ltd., and they supply cell-based products for the cell therapy product and various human and animal cells or tissues (Table 6).

The front industry companies of the scaffold market for stem cells will be specialized companies, institutions and general hospitals developing cell therapy products. Korean cell-therapy-product-related companies are Anterogen, Medipost, Cha Biotech, Pharmicell, SewonCellontech, and Tegoscience. Table 7 shows the Korean companies who developed cell therapy product approved by the FDA in US as well as their products. Also, 44 hospitals including Seoul ASAN Medical Center, Severance Hospital, Samsung Medical Center, Seoul National University Hospital, and Seoul St. Mary's Hospital were investigated to be specialized hospitals [27].
Around the world, there are many major companies developing stem cell products such as Osiris Therapeutics, NuVasive, Aastrom Biosciences, BrainStorm Cell Therapeutics, Genzyme, International Stem Cell, Medcell Biosciences, Medistem, Opexa Therapeutics, Plureon, Revicor and StemCyte. Many of them are forming partnerships with pharmaceutical companies, and most of them are known to be producing products for the treatment of burns, wounds and skeletal defects (Table 8).

\section{Conclusions}

There can be differences in industrial prospects depending on the market and product scope of stem cells, but in most of the global market analysis report, rapid growth of the stem cell market is prospected.

Through the positive influences of unfulfilled medical markets for treatment for diseases such as leukemia and nervous system diseases and active stem cell research support by the government, stem cell bank services, and the activation of medical tourism, growth in stem-cellrelated industries is expected. However, there are factors hindering the industrial activation such as high treatment cost and government regulation due to ethical concerns, but opportunity factors such as the continuous increase of neurodegenerative diseases such as Parkinson's disease, the growth of emerging countries such as India and China, and the increase of availability on new drug development are prospected to lead to growth in the stem cell industry.

Therefore, the biomaterials included in the element technology of the stem cell and regenerative medicine

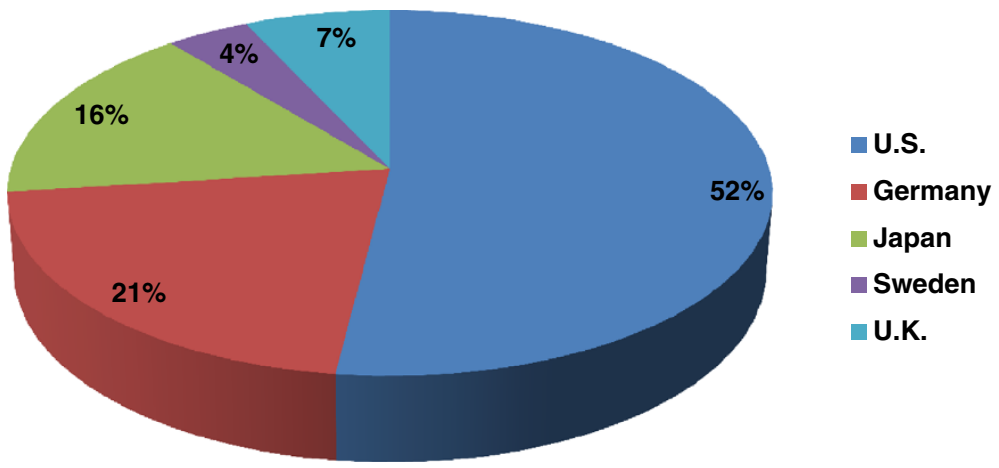

Figure 2 Geographic distribution of tissue engineering firms in major markets [18]. 
Table 5 Most purchased from suppliers of 3D cell culture consumables and instruments [26]

\begin{tabular}{|c|c|c|c|c|}
\hline Company & Primary supplier & Secondary supplier & $\%$ of all selections & Total no. of selections \\
\hline 3D Biomatrix & $0 \%$ & $3 \%$ & $2 \%$ & 2 \\
\hline 3D Biotek & $1 \%$ & $6 \%$ & $4 \%$ & 5 \\
\hline BD Biosciences & $41 \%$ & $11 \%$ & $27 \%$ & 35 \\
\hline Bellbrook Labs & $0 \%$ & $2 \%$ & $1 \%$ & 1 \\
\hline CellASIC & $3 \%$ & $0 \%$ & $2 \%$ & 2 \\
\hline CELLnTEC & $1 \%$ & $3 \%$ & $2 \%$ & 3 \\
\hline Corning & $9 \%$ & $14 \%$ & $11 \%$ & 15 \\
\hline Electrospinning Company & $0 \%$ & $0 \%$ & $0 \%$ & 0 \\
\hline EMD-Millipore & $3 \%$ & $2 \%$ & $2 \%$ & 3 \\
\hline Global Cell Solutions & $4 \%$ & $2 \%$ & $3 \%$ & 4 \\
\hline GlycosanBiosystems & $0 \%$ & $2 \%$ & $1 \%$ & 1 \\
\hline Hamilton Company & $0 \%$ & $2 \%$ & $1 \%$ & 1 \\
\hline Insphero & $4 \%$ & $3 \%$ & $4 \%$ & 5 \\
\hline InvivoSciences & $0 \%$ & $2 \%$ & $1 \%$ & 1 \\
\hline Kuraray & $0 \%$ & $0 \%$ & $0 \%$ & 0 \\
\hline Life Technologies (Invitrogen) & $16 \%$ & $16 \%$ & $16 \%$ & 21 \\
\hline Lonza & $3 \%$ & $10 \%$ & $6 \%$ & 8 \\
\hline MatTek & $3 \%$ & $2 \%$ & $2 \%$ & 3 \\
\hline Microtissues & $0 \%$ & $0 \%$ & $0 \%$ & 0 \\
\hline OrganDot 3D & $0 \%$ & $0 \%$ & $0 \%$ & 0 \\
\hline QGel Bio & $0 \%$ & $0 \%$ & $0 \%$ & 0 \\
\hline RealBio Technology & $0 \%$ & $0 \%$ & $0 \%$ & 0 \\
\hline RegeneMed & $1 \%$ & $1 \%$ & $1 \%$ & 1 \\
\hline Reinnervate & $1 \%$ & $2 \%$ & $2 \%$ & 3 \\
\hline Scivax & $3 \%$ & $2 \%$ & $2 \%$ & 2 \\
\hline Sigma-Aldrich & $4 \%$ & $8 \%$ & $8 \%$ & 11 \\
\hline Synthecon & $1 \%$ & $2 \%$ & $2 \%$ & 2 \\
\hline TAP Biosystems & $0 \%$ & $1 \%$ & $1 \%$ & 1 \\
\hline Tissue Growth Technologies & $0 \%$ & $0 \%$ & $0 \%$ & 0 \\
\hline ThermoScientific & $0 \%$ & $2 \%$ & $2 \%$ & 2 \\
\hline Zyoxel & $0 \%$ & $0 \%$ & $0 \%$ & 0 \\
\hline Total & 69 & 63 & 132 & 132 \\
\hline
\end{tabular}

industry, in other words, the scaffold market, is also a field expected to expand in its market together with the growth of the front industry. The market size of threedimensional cell culture related consumables was estimated to grow at an annual average rate of $23.5 \%$ from 34 million dollars in 2011 to 64 million dollars in 2014, and it is prospected to grow strongly after 2014 [26].

Also, as results of the market research of industries related to stem cells and regenerative medicine to estimate the Korean and world scaffold market sizes, the 2013 world scaffold element technology market was 457 million dollars and expected to grow $13.4 \%$ annually, resulting in an expansion to 1.063 billion dollars in 2020 . The
Korean scaffold element technology market was about 22 million dollars in 2013 and is expected to have a steady growth of $13.4 \%$, the same as the world annual average growth rate, which would result in a market size of 52 million dollars by 2020 . By comparing with growth rate of medical materials and medicine sales, the future scaffold element technology market is judged to be higher in growth possibility.

The scaffold market is in the initial market stage of research and technology development progressing actively, and market is difficult to identify accurately due to the frequent M\&A by the companies in the market and many problems that need to be overcome technologically, but 


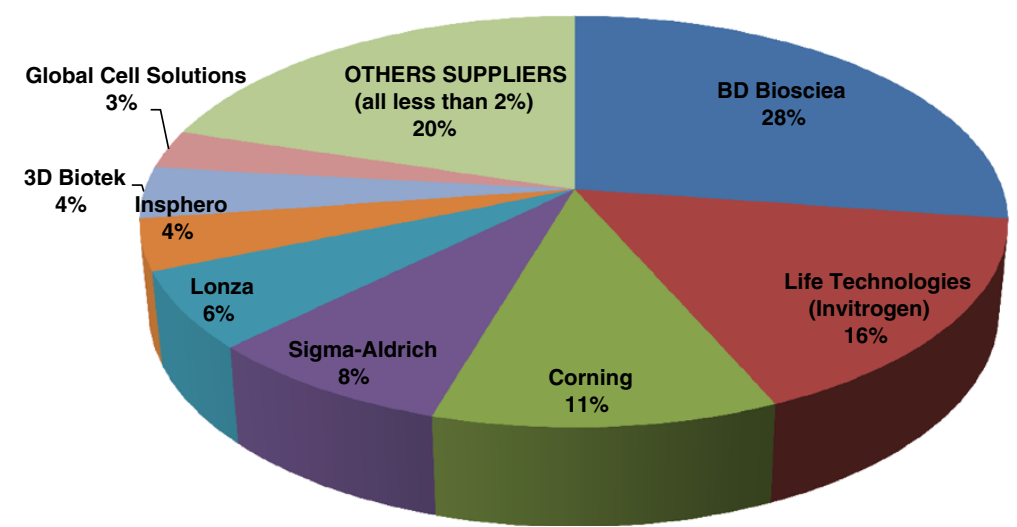

Figure 3 Estimated supplier share of 3D consumables and instruments market [26].

\section{Table 6 Selected suppliers of cells and tissues [18]}

\begin{tabular}{|c|c|}
\hline Company & Product \\
\hline $\begin{array}{l}\text { American Type Culture Collection } \\
\text { (ATCC) }\end{array}$ & Supplies many types of cells lines and bioproducts. \\
\hline Asterand plc & $\begin{array}{l}\text { Provides human biomaterials for drug testing(human primary cells and cell lines, RNA, tissue microarrays, frozen } \\
\text { and fixed human tissues) }\end{array}$ \\
\hline $\begin{array}{l}\text { ATCC-LCG Promochem } \\
\text { Partnership }\end{array}$ & Facilitates distribution of ATCC culture and bioproducts to life science researchers in Europe \\
\hline BioE, & $\begin{array}{l}\text { Multi-Lineage Progenitor cellTM, a human umbilical cord blood-derived, clonal, multipotent stem cell line; unique } \\
\text { cell reagents. }\end{array}$ \\
\hline Life Technologies & Keratinocytes and other epithelial cells, endothelial cells, fibroblasts, etc. \\
\hline Cascade Biologics & Keratinocytes and other epithelial cells, endothelial cells, fibroblasts, etc. \\
\hline $\begin{array}{l}\text { Cell Systems Biotechnologie } \\
\text { Vertrieb GmbH }\end{array}$ & $\begin{array}{l}\text { Cell biology products including human primary cells, 3D skin cell systems, and cell models for angiogenesis, } \\
\text { blood-barrier, and inhalation toxicology. }\end{array}$ \\
\hline Lonza Group Ltd. & 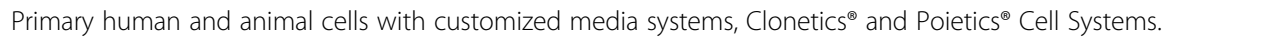 \\
\hline $\begin{array}{l}\text { Musculoskeletal Transplant } \\
\text { Foundation(MTF) }\end{array}$ & Pieces of human bone, skin, and other tissues; FlexHD, an acellular dermal matrix, primarily for surgery. \\
\hline National Cancer Institute(NCl) & Tissues, cell lines, databases, arrays, etc. primarily for cancer research. \\
\hline $\begin{array}{l}\text { National Cell Culture Center } \\
\text { (NCCC) }\end{array}$ & Division of Biovest International; provides customized, large-scale cell culture services. \\
\hline $\begin{array}{l}\text { National Disease Research } \\
\text { Interchange(NDRI) }\end{array}$ & Human tissues, organs, and derivatives for research. \\
\hline $\begin{array}{l}\text { National Stem Cell Bank(NSCB) at } \\
\text { WiCell }\end{array}$ & $\begin{array}{l}\text { Established to acquire, characterize and distribute the } 21 \text { human embryonic stem cell lines and their sub-clones } \\
\text { to federally funded research programs; they currently have } 13 \text { of the } 21 \text { cell lines in the federal registry. }\end{array}$ \\
\hline $\begin{array}{l}\text { NIH Human Embryonic Stem Cell } \\
\text { Registry }\end{array}$ & $\begin{array}{l}\text { Lists the derivations of stem cells that are eligible for federal funding and provides contact information for } \\
\text { acquiring the cell lines. }\end{array}$ \\
\hline OnCore UK & Human specimens for cancer research \\
\hline ProBioGen AG & $\begin{array}{l}\text { Specializes in mammalian cell engineering and cell culture: design of custom immortalized cell lines for vaccine } \\
\text { and protein production, or for other customer needs. }\end{array}$ \\
\hline SciKon Innovation, Inc. & Human matrix cell culture surface; human stellates; human hepatocyte cryopriserved cells. \\
\hline Tebu-bio laboratories & $\begin{array}{l}\text { Various cryopreserved primary cells; cell biology services such as cell amplification, differentiation, transfection, } \\
\text { mycoplasma testing; establish cellular models overexpressing of silencing a protein of interest. }\end{array}$ \\
\hline Zen Bio & Human adult stem cells, preadipocytes, adipocytes, primary human hepatocytes; specialized media. \\
\hline
\end{tabular}


Table 7 Cell therapy products approved in South Korea [18]

\begin{tabular}{|c|c|c|}
\hline Company & Product & Indication \\
\hline \multirow[t]{3}{*}{ Anterogen } & Adipocel & Adipose stem cell \\
\hline & Cupistem $^{\circledast}$ & Adipose stem cell \\
\hline & Queencell ${ }^{\oplus}$ & Autologous Mesenchymal stem cell \\
\hline \multirow{2}{*}{$\begin{array}{l}\text { Sewon } \\
\text { Cellontech }\end{array}$} & RMS ossron & Cartilage cell \\
\hline & Chondron & Bone stem cell \\
\hline \multirow[t]{2}{*}{ Chabiotech } & Hyalograft-3D+ & Autologous skin fibroblasts \\
\hline & Autostem & Adipose cell \\
\hline Creagene & Creavax-RCC+ & Dendritic cell \\
\hline FCB-Pharmicell & $\begin{array}{l}\text { Heartcellgram- } \\
\text { AMl }\end{array}$ & Autologous Bone Marrow-Derived Mesenchymal stem cell \\
\hline Green Cross cell & Immuncell-LC ${ }^{\oplus}$ & $\begin{array}{l}\text { Adjuvant therapy for patients whose tumor has been removed after curative resection for Hepatocellular } \\
\text { Carcinoma }\end{array}$ \\
\hline MCTT & KERAHEAL ${ }^{T M}$ & Human epidermal keratinocyte \\
\hline Medipost & Cartistem $^{\circledast}$ & Human umcilical cord blood-derived mesenchymal stem cell product for cartilage regeneration \\
\hline S-Bio Medics & Cureskin & Autologous fibroblast therapy \\
\hline \multirow[t]{2}{*}{ Tegoscience } & Holoderm ${ }^{\oplus}$ & Epidermal cell \\
\hline & Kaloderm ${ }^{\circledast}$ & Epidermal cell \\
\hline
\end{tabular}

many specialized companies and research institutes, both in Korea and in other parts of the world, are actively conducting research to develop scaffolds for regenerative medicine that can perform a similar role as the extracellular matrix, and policies and systems on stem cells and regenerative medicine are quickly expanding and being established cross-nationally for the quick commercialization of products. Therefore, the future prospects of the stem cells and regenerative medicine industry and other relevant industries are very bright.

Table 8 Leading commercial cell therapy products and companies in 2012 [18]

\begin{tabular}{|c|c|c|}
\hline Company & Product & Indication \\
\hline Advanced Biohealing, a Shire Company & Dermagraft & Diavetic foot ulcers \\
\hline Allosource distributed by NuVasive & Osteocel & Skeletal defects \\
\hline Alphatec Spine & PureGen & Musculoskeletal defects \\
\hline Altrika & Myskin & Wounds \\
\hline Altrika & Cryoskin & Wounds, burns \\
\hline AvitaMadical & ReCell & Wounds, burns, scars \\
\hline BioDlogics(distributed by America) & BioDfentor & Wound healing, soft tissue defects, skeletal defects \\
\hline BioDlogics(distributed by America) & BioDfence & Wound healing, soft tissue defects, skeletal defects \\
\hline Dendreon & Provenge & Prostate cancer \\
\hline Fibrocell & laVin & Nasolabial fold wrinkles(smile lines) \\
\hline Genzyme(a Sanofi company) & Carticel & Articular cartilage repair \\
\hline Genzyme(a Sanofi company) & Epicel & Severe burn and skin replacement \\
\hline Genzyme(a Sanofi company) & $\mathrm{MACl}$ & Articular cartilage repair \\
\hline NuTech & NuCel & Wound healing, soft tissue defects, skeletal defects \\
\hline Organogenesis & Appligraf & Venous leg ulcers, diabetic foot ulcers \\
\hline Organogenesis & GINTUIT & Gingival and alveolar mucosal surface defects \\
\hline Orthofix & Trinity Evolution & Musculoskeletal defects \\
\hline Osiris Therapeutics & Grafix & Acute and chronic wounds \\
\hline TiGencs & ChondroCelect & Articular cartilage repair \\
\hline Zimmer Orthobiologics & DeNovo NT & Articular cartilage repair \\
\hline
\end{tabular}




\section{Competing interests}

The authors declare that they have no competing interests.

\section{Authors' contributions}

SL primarily worked on the research. TK participated in the design of the research and helped to draft the manuscript. EKC helped to perform the statistical analysis. JWL conceived of the research and participated in its design and coordination as the corresponding author. All authors read and approved the final manuscript.

\section{Author details}

'Techbiz, Room No. 903, 26 Seochojoongang-Ro, Seocho-Gu, Seoul 137-918, Korea. ${ }^{2}$ KISTI, 66 Heogi-ro, Dongdeamoon-gu, Seoul 130-741, Korea.

Received: 16 July 2014 Accepted: 18 August 2014

Published: 1 September 2014

\section{References}

1. Visiongain: Stem Cell Technologies World Market Outlook 2011-2021. ; 2010.

2. Mano JF, Sousa RA, Boesel LF, Neves NM, Reis RL: Bioinert, biodegradable and injectable polymeric matrix composites for hard tissue replacement: state of the art and recent developments. Composites Sci Technol 2004, 64(6):789-817

3. Shin H, Jo S, Mikos AG: Biomimetic materials for tissue engineering. Biomaterials 2003, 24(24):4353-4364.

4. Atala A: Engineering organs. Curr Opin Biotechnol 2009, 20(5):575-592.

5. Atala A: Regenerative medicine and tissue engineering in urology. Urol Clin North Am 2009, 36(2):199-209.

6. Atala A: Tissue engineering of reproductive tissues and organs. Fertil Steril 2012, 98(1):21-29.

7. Atala A, Kasper FK, Mikos AG: Engineering complex tissues. Sci Trans/ Med 2012, 4(160):Article ID: 160rv12160rv12.

8. $\operatorname{Rim} \mathrm{N}$, Lee $\mathrm{Y}, \mathrm{Kim} \mathrm{S}$, Shin H: Current status and prospect of biomaterials as tissue substitutes in regenerative medicine. Korean Ind Chem News 2010, 13(6):2-17.

9. Chen F, Yoo JJ, Atala A: A cellular collagen matrix as a possible "off the shelf" biomaterial for urethral repair. Urology 1999, 54(3):407-410.

10. Chun S, Lim GJ, Kwon TG, Kwak EK, Kim BW, Atala A, Yoo JJ: Identification and characterization of bioactive factors in bladder submucosa matrix. Biomaterials 2007, 28(29):4251-4256.

11. Yoo JJ, Meng J, Oberpenning F, Atala A: Bladder augmentation using allogenic bladder submucosa seeded with cells. Urology 1998, 51(2):221-225.

12. Kim B, Atala A, Yoo JJ: A collagen matrix derived from bladder can be used to engineer smooth muscle tissue. World J Urol 2008, 26(4):307-314.

13. Korea Food and Drug Administration: A Study on Evaluation Criteria for Quality of Mesenchymal Stem Cell based Tissue Engineering Products: Searching for Molecular Biological Method. ; 2007.

14. Lee $H$, Khang G, Kim M, Rhee JM, Lee I, Min B: Scaffold for tissue engineering. Tissue Eng Regen Med 2006, 3(4):1738-2696.

15. LG Economic Research Institute: StemCell: Gap between Possibility and Reality. 2013.

16. Ehwa Womans University: Research on the Evaluation Method for Bioactive Medical Devices. ; 2009.

17. Choi B, Park S: Current status and future perspectives of stem cells and regenerative medicine. Hanyang Med Rev 2012, 32(3):127-133.

18. TriMark Publication: Regenerative Medicine Markets. ; 2013.

19. Lee $\mathrm{CH}$, Singla A, Lee Y: Biomedical applications of collagen. Int J Pharm 2001, 221(1):1-22.

20. Job L, van Susante $C$, Jeroen $P$, Pieter B, van Kuppevelt TH, van Beuningen $H$, van der Kraan PM, Veerkamp JH, van den Berg WB, René $P$, Veth $H$ : Linkage of chondroitin-sulfate to type I collagen scaffolds stimulates the bioactivity of seeded chondrocytes in vitro Biomaterials. Biomaterials 2001, 22(17):2359-2369.

21. Murray MM, Rice K, Wright RJ, Spector M: The effect of selected growth factors on human anterior cruciate ligament cell interactions with a three-dimensional collagen-GAG scaffold. J Orthop Res 2003, 21(2):238-244

22. Lee $\mathrm{S}, \mathrm{Yoo} \mathrm{J}$, Atala A: Recent applications of polymeric biomaterials and stem cells in tissue engineering and regenerative medicine. Polymer 2014, 38(2):113-128
23. Shinhan Investment Corp: Sector Report: Stem-Cell Theraphy Products. 2011.

24. 10 Growth Strategies for Stem Cell Industry. Korea Health Industry Development Institute; 2005.

25. Investment Strategies for Stem Cell Technology. Korean Ministry of Education Korean Ministry of Health and Welfare, Korean Ministry of Knowledge Economy, Korean Ministry of Agriculture, Food and Rural Affairs. 2012.

26. HTStec: 3D Cell Culture Trends 2011. 2011.

27. Korea Health Industry Development Institute: Medical Resource Statistics Handbook. 2012

doi:10.1186/2055-7124-18-11

Cite this article as: Lee et al:: The market trend analysis and prospects

of scaffolds for stem cells. Biomaterials Research 2014 18:11.

\section{Submit your next manuscript to BioMed Central and take full advantage of:}

- Convenient online submission

- Thorough peer review

- No space constraints or color figure charges

- Immediate publication on acceptance

- Inclusion in PubMed, CAS, Scopus and Google Scholar

- Research which is freely available for redistribution

Submit your manuscript at www.biomedcentral.com/submit
C Biomed Central 